\title{
SUSCEPTIBILITY OF CYPRINID AND NON-CYPRINID FISH CELL LINES TO KOI HERPESVIRUS (KHV)
}

\author{
Tuti Sumiati") \# and Agus Sunarto**) \\ ") Research Institute for Freshwater Aquaculture. Jl. Sempur No. 1, Bogor, West Java \\ ${ }^{*}$ Research Center for Aquaculture. Jl. Ragunan 20, Pasar Minggu, Jakarta 12540
}

\begin{abstract}
Koi herpesvirus (KHV) is an emerging virus that infects koi and common carp (Cyprinus carpio) with mortality up to $95 \%$ within 7 days. The disease is rapidly spreading worldwide including to Indonesia. However, it has only been documented in koi and common carp. The aim of this research was to evaluate the susceptibility of fish cell cultures originated from cyprinid and non-cyprinid fish to KHV. Koi Fin (KF-1) and Koi Tail (KT-2) cell lines derived from koi carp and SSN-1 cells originated from fry of striped snakehead were used in this study. The cells were inoculated with tissue extract of KHV-infected koi carp (experiment 1) and virus stock of KHV (experiment 2). The cultures were incubated at $22^{\circ} \mathrm{C}$ and the onset and type of cytophatic effect (CPE) were observed for 21 days post inoculation. The results of experiment 1 showed that CPE was observed in KT-2 at day 6 post inoculation. In the experiment 2, however CPE was observed in KF-1 and KT-2 cells at day 4 post infection. CPE was not observed in SSN-1 of either experiment 1 or experiment 2. CPE was characterized by extensive vacuolization of the infected cells. Polymerase chain reaction (PCR) assay of cell and tissue culture supernatants confirmed that KF-1 and KT-2 showing CPE were indeed infected with KHV. The results indicated that KF-1 and KT-2 cells were susceptible and SSN-1 was resistant to KHV. The implication of these findings was also discussed in the paper.
\end{abstract}

KEYWORDS: susceptibility, fish cell culture, KHV, cytophatic effect, PCR

\section{INTRODUCTION}

Koi herpesvirus (KHV) is an emerging virus that infects koi and common carp (Cyprinus carpio). The mortality rate was $80 \%-95 \%$ in fry as well as in adult fish (Perelberg et al., 2003). The disease is spreading rapidly worldwide and causing huge economic losses in the USA, UK, Israel, Eastern European countries, Asian and Africans countries since 1998 (Hedrick et al., 2000; Neukrich \& Kunz, 2001; Hoffman et al., 2002; Way et al., 2002; Perelberg et al., 2003; Ronen et al., 2003; Haenen et al., 2004; Sano et al., 2004; Tu et al., 2004; Sunarto et al., 2005a).
KHV (Hedrick et al., 2000) is also known as carp nephritis and gill necrosis virus (CNGV) (Ronen et al., 2005) and Cyprinid herpesvirus3 (CyHV-3) (Waltzek et al., 2005). The virus is an enveloped virus with icosahedral nucleocapsid of 100-110 nm in diameter, and belongs to the family of Alloherpesviridae. The viral genome is linear double stranded DNA molecule of $295 \mathrm{Kbp}$, the biggest genome in the order of Herpesvirales (Hedrick et al., 2005; Hutoran et al., 2005).

No drugs or pharmaceuticals have been found to be effective to combat the viral disease. However, applying good aquaculture

\# Corresponding author. RResearch Institute for Freshwater Aquaculture. Jl Sempur No. 1, Bogor, Indonesia. Tel.: +

E-mail address: tuti.sumiati@yahoo.co.id 
practices (GAPs) such as biosecurity and vaccination programme may prevent the outbreak and reduce the mortality rate caused by the disease (Sunarto et al., 2005a; Sunarto et al., $2005^{c}$ ). The epidemiology and control of KHV in Indonesia has been extensively studied (Sunarto et al., 2005a; Sunarto et al., 2005'; Sunarto \& Cameron, 2005; Sunarto \& Cameron, 2006). The reports showed that KHV only affects koi and carp, but not other fish species. Tilapia, giant gouramy, and other freshwater fishes reared in the same pond with diseased carp showed no signs of the disease or suffered mortality from it. However, scientific information on whether the virus is able to infect non-cyprinid fish cells is limited. Therefore, the aim of this study was to investigate the susceptibility of fish cell cultures originated from cyprinid (KF-1 and KT-2 cells) and non-cyprinid fish (SSN-1 cells) to KHV infection.

\section{METHODS}

Cell culture preparation. Three cell lines originated from cyprinid and non-cyprinid fish were used in this study. Koi fin cell line (KF-1), established from fin of koi (Cyprinus carpio) (Hedrick et al., 2000), was kindly donated by Prof Ronald Hedrick (University of California at Davis, USA). Koi tail cell line (KT -2), developed from tail of koi, was a newly developed cell line in our laboratory (Sunarto et al., 2005). Striped snakehead cell (SSN-1) was initiated from the whole fry tissue of Channa striatus of the family of Channidae. The cell was imported from the University of Stirling, UK. All cell lines were maintained in Leibovitz L-15 medium supplemented with antibiotics and $10 \%$ serum. Only cell cultures showed confluency of more than $80 \%$ were used for the study. The cells for experiment 1 and 2 were prepared using the same methods. In the experiment 1 , the cell lines were inoculated with tissue extract (TE) from KHV-infected fish and in the experiment 2 , the cells were inoculated with virus stock of KHV.

\section{Tissue extract preparation}

Tissue extract was prepared from diseased fish according to the standard procedures (Freshney, 1994) with minor modifications. Pool of kidneys, spleens and gills were homogenized and diluted 1:10 with Hanks Balanced Salts Solution (HBSS) supplemented with $2 \%$ Fetal Bovine Serum (FBS). Tissue suspension was centrifuged at $1,500 \mathrm{~g}$ for 15 minutes at $4^{\circ} \mathrm{C}$ to deposit tissue debris. Clarified supernatant was removed and diluted 1:5 with HBSS supplemented with $2 \%$ FBS. Diluted tissue extract was filtered through $0.45 \mu \mathrm{m}$ membrane filter into sterile container. A hundred microliter of filtered TE was separately subjected to PCR assay.

Inoculation of cell culture. Two replication of cell cultures were inoculated with TE in 1:50 dilution (experiment 1 ) at the rate of approximately $1 \mathrm{~mL}$ per $25 \mathrm{~cm}^{2}$ of cell sheet. Control cell cultures were inoculated at the same time with an equal volume of HBSS. Following an adsorption period of 30-45 minutes, a fresh culture medium was added into the culture flask. The cultures monolayer were incubated at $22^{\circ} \mathrm{C}$ and observed daily for the evidence of Cytophatic Effect (CPE). The same procedure was used for the inoculation of cell culture with virus stock of KHV (experiment 2).

\section{Passage of virus-infected cells}

Following the appearance of CPE, a $100 \mu \mathrm{L}$ aliquot of Tissue Culture Supernatant (TCSN) was used to inoculate a $25 \mathrm{~cm}^{2}$ flask of KT-2 cells with $80 \%$ confluent. The cultures were incubated at $22^{\circ} \mathrm{C}$ and observed daily for the evidence of CPE. A hundred microliter of TCSN and the remaining cells were separately subjected to PCR assay.

\section{Polymerase chain reaction}

PCR test against KHV was conducted using commercially available PCR kits (IQ2000, Taiwan) according to the manufacturer's protocol. The IQ2000 PCR kits produced semi-quantitative results of $229 \mathrm{bp}$ (light KHV infection) and/or $440 \mathrm{bp}$ (severe KHV infection). Prior to virus isolation, tissue extract of pooled kidney, spleen and gills were tested against KHV using PCR to confirm that the fish was indeed infected with KHV. The cells and the cell-free TCSN of virus-infected cell cultures were also tested using PCR assay.

\section{RESULT AND DISCUSSION}

Koi was collected from fish farm experiencing mass mortality with clinical signs typical to KHV infection. PCR test against KHV using commercially available kit confirmed that the outbreak was caused by KHV. The results of this semi-quantitative PCR assay revealed that the koi had severe infection (Figure 1). 


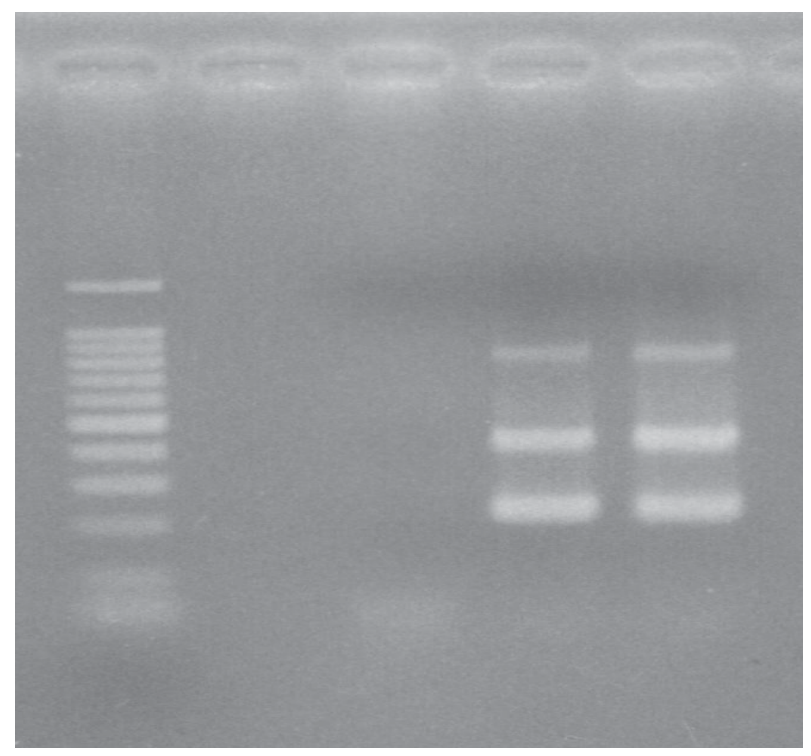

Figure 1. PCR detection against KHV on tissue extract of sick koi used for viral isolation indicated severe infection of KHV. Lane 1. DNA marker of $100 \mathrm{bp}, 2$. blank, 3. negative control, 4. sick koi (positive), 5. positive control

Three koi samples with damaged gills signs varied from excess mucus production, white patches to severe necrosis were used for the tissue extract preparation. Pool of kidney, spleen and gills were used for viral isolation using KT-2, KF-1 and SSN-1 cell cultures. The development of cytophatic effect was first observed at day 6 post inoculation of the tissue extract in KT-2 cell line. The cells showed extensive vacuolization, retracted from the flask and completely detached after 2 weeks post inoculation. CPE was not observed in KF1 and SSN-1 cell lines inoculated with the same tissue extract (Figure 2).

Primary virus and its three consecutive passages induced CPE at day 4 post inoculation. The CPE was characterized by an extensive vacuolization witihin the cells (Figure 3 ).

The PCR assay of cell and cell-free TCSN of the primary culture and its consecutive passages confirmed that the KT-2 cells were indeed infected with KHV (Table 1).

Culture fluid (TCSN) of the $3^{\text {rd }}$ passage of KHV was used for inoculation of KT-2, KF-1 and SSN-1 cell cultures (experiment 2). In experiment 2, the development of cytophatic effect was first observed at day 4 post inoculation of the cultures. However, CPE was only observed in the KF-1 and KT-2 cell lines, but not in SSN-1 cell line (Figure 4). The infected cells showed extensive vacuolization typical to KHVinduced CPE, retracted and completely detached from the flask after two weeks post inoculation.

Table 2 summarized the susceptibility of fish cell cultures originated from cyprinid and non-cyprinid fish to Koi herpesvirus. The table showed that the tissue extract prepared from $\mathrm{KHV}$-infected fish was only induced CPE in KT2 cell line (experiment 1 ). However, in experiment 2 where the cell cultures were inoculated with virus stock of KHV, CPEs were observed in KT-2 and KF-1 cell lines. CPE was not observed in SSN-1 of either experiment 1 or experiment 2.

Koi herpesvirus was first isolated from outbreaks of carp suffering mass mortality in Israel and the USA (Hedrick et al., 2000). Although the disease has spread to fish farm worldwide, it has presently only documented in koi and common carp. In Indonesia, KHV was first isolated from pool of kidney, spleen and 

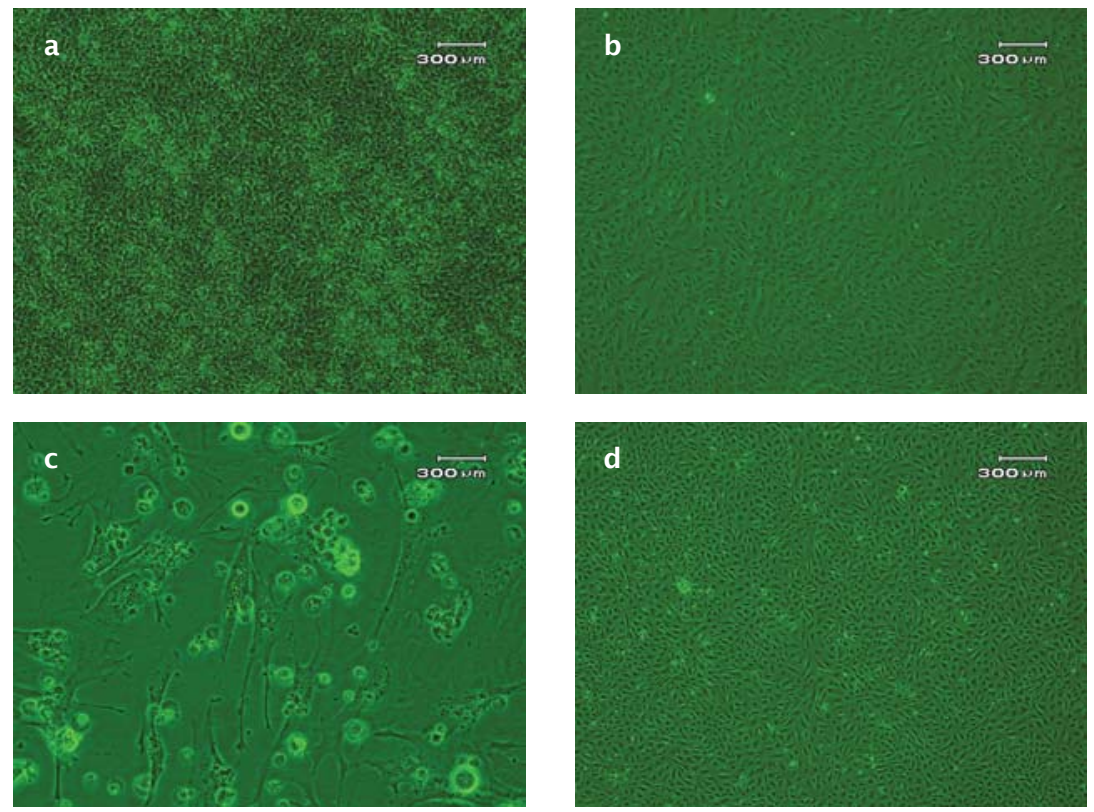

Figure 2. Photograph of experiment 1 : cell cultures infected with tissue extract at day 10 post inoculation. a. SSN-1 cell, b. KF-1 cell, c. KT-2 cell, d. Un-infected KT-2 cell (control flask). Note the cytopathic effect in KT-2 infected cells (c)
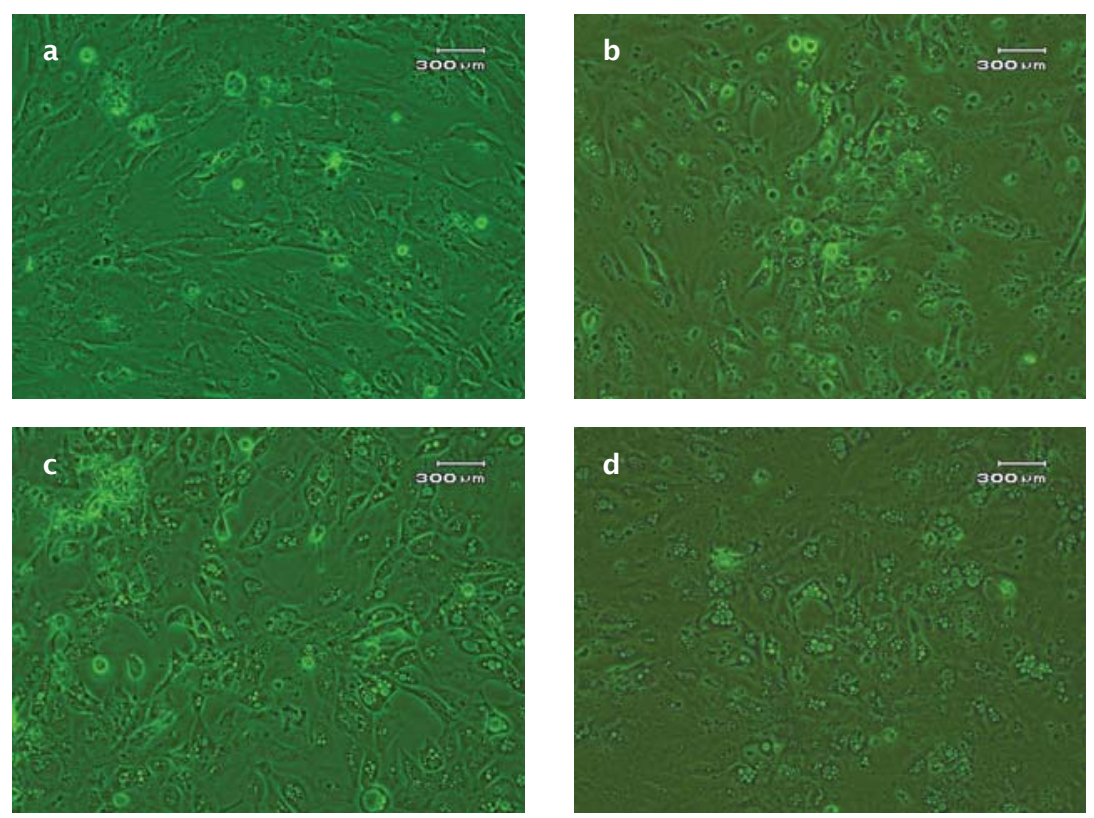

Figure 3. Photograph of KT-2 cells infected with various passages of KHV at day 7 post inoculation a. Primary virus of KHV, b. Passage 1, c. Passage 2 and d. Passage 3. All the virus preparations induced CPE characterized by an extensive vacuolization of infected cells 
Table 1. PCR assay against KHV of infected KT-2 cells and its cell-free tissue culture supernatant

\begin{tabular}{lcc}
\hline \multirow{2}{*}{ Virus passage } & \multicolumn{2}{c}{ PCR assay } \\
\cline { 2 - 3 } & Cells & Cult ure fluid \\
\hline Primary & + & + \\
Passage 1 & + & + \\
Passage 2 & + & + \\
Passage 3 & + & + \\
\hline
\end{tabular}
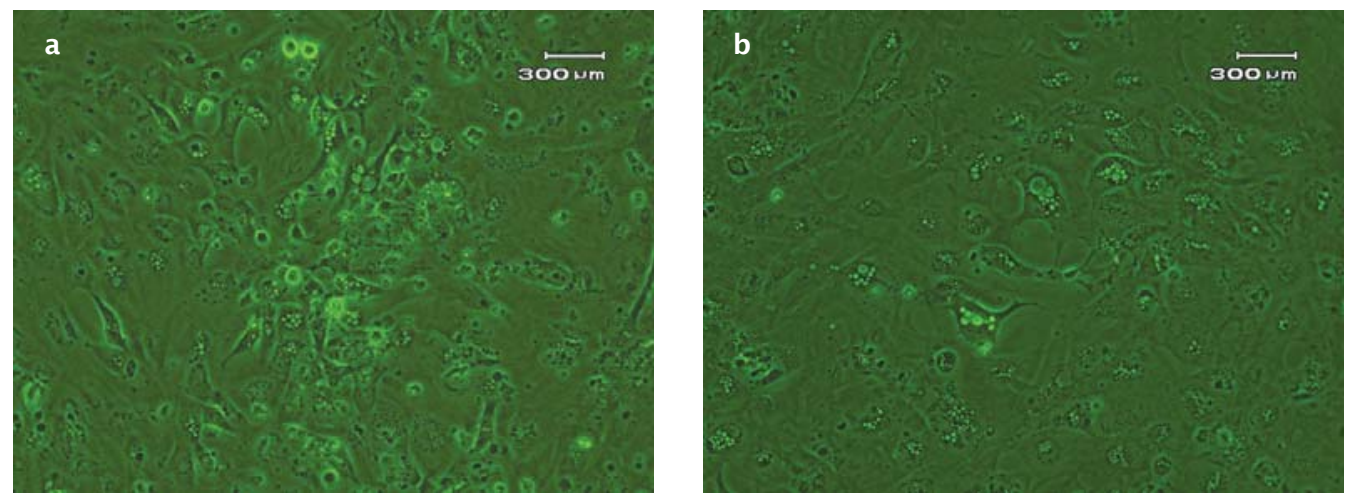

Figure 4. Photograph of experiment 2: cell cultures inoculated with virus stock of KHV. The virus only induced CPE at KT-2 cell line (a) and KF-1 cell line (b)

Table 2. The susceptibility of fish cell cultures to Koi herpesvirus

\begin{tabular}{lcc}
\hline Cell line & $\begin{array}{c}\text { Inoculation with } \\
\text { tissue extract } \\
\text { (experiment 1) }\end{array}$ & $\begin{array}{c}\text { Inoculation with virus } \\
\text { stock of KHV } \\
\text { (experiment 2) }\end{array}$ \\
\hline $\mathrm{KT}-2$ & + & + \\
$\mathrm{KF}-1$ & - & + \\
$\mathrm{SSN}-1$ & - & - \\
\hline
\end{tabular}

Note: + : showing CPE; - : not showing CPE

gills of koi which were collected from several farms suffered mass mortality in West Java using KT-2 cell line (Sunarto et al., 2005' $)$. The development of CPE was first observed at day 6 after inoculation with tissue extract prepared from diseased fish. The type of CPE in this KT-2 cells was identical to CPE in KF-1 cells infected with $\mathrm{KHV}$ as described previously (Hedrick et al., 2000). However, the onset of CPE in KT-2 (4-6 days) was faster than the onset of CPE in KF-1 cells (7-10 days).
The CPE at KF-1 and KT-2 cell lines was characterized by an extensive vacuolization of the cell. The vacuolated cells were swollen, rounded, and some of the cells were fused with adjacent cells. The cells were retracted from the flask and completely detached after 2 weeks post inoculation. Although KHV can grow in both KF-1 and KT-2 cells, but experiment 1 showed that KT-2 was more sensitive for virus isolation of KHV from Indonesian fish than KF-1 cell. In other word, the use of KT-2 cells in 
an attempt to isolate KHV from Indonesian fish increased the isolation rate. However, further research is needed to ascertain the exact isolation rate of KHV using KT-2 cell line.

KT-2 and KF-1 cell lines were originated from tail and fin of koi (Cyprinidae), respectively. SSN-1 cell line was derived from whole fry tissue of striped snakehead (Channidae). Table 2 showed that KHV only grew and caused CPE in the cell cultures originated from cyprinid fish. The results are in line with the previous work Davidovich et al., 2007) that most cyprinid cell cultures are susceptible to CyHV3 (KHV). However, other carp cell lines (Epithelioma Papulosum Cyprini, EPC) was restrictive to the virus. On the other hand, SSN-1, a noncyprinid cell line, was resistant to KHV. It is interesting to note that the results of the experiments in cell cultures perfectly reflect the situation in fish farm in which KHV only affects koi and carp.

As there are no treatment for $\mathrm{KHV}$, attempt to control KHV outbreak in farm level is focused on the prevention of getting infected with the virus by applying biosecurity concept. However these practices may only be effective for isolated farm such as indoor koi farm, but not for raceway and cage culture system in open water (Sunarto et al., 2005'). In this case, good aquaculture practices (GAPs) such as vaccination programme would be methods of choice. The success of the isolation of KHV from Indonesian fish using KT-2 cell and the subsequent application of the cell culture for the study of biological properties of KHV in vivo, may lead to a better understanding of the pathogenesis of the virus both in vivo and in vitro. In long term, the data generated from these researches may provide a basic step toward the development of vaccination programme to control the outbreaks of koi herpesvirus.

\section{CONCLUSION}

Cell lines originated from cyprinid fish (KT-2 and KF-1) were susceptible to Koi herpesvirus. However, cell line derived from noncyprinid fish (SSN-1) was resistant to KHV. KT-2 cell was more sensitive for isolation of KHV from Indonesian fish than KF-1 and SNN-1 cells.

\section{REFERENCES}

Davidovich, M., Dihson, A., Illouze, M., \& Kotler, M. 2007. Susceptibility of cyprinid cultured cells to cyprinid herpesvirus 3. Arch. Virol., 152: 1,541-1,546.

Freshney, R.I. 1994. Culture of animal cells: A manual of basic technique. $3^{\text {rd }}$ ed. WileyLiss. Inc. USA, 486 pp.

Haenen, O.L.M., Way, K., Bergmann,S.M., \& Ariel, E. 2004. The emergence of koi herpesvirus and its significant to European aquaculture. Bull. Eur. Ass. Fish Pathol., 24: 293-307.

Hedrick, R.P., Gilad, O., Yun, S.C., Spangenberg, J.V., Marty, G.D., Nordhausen, R.W., Kebus, M.J., Bercovier, H., \& Eldar, A. 2000. A herpesvirus associated with mass mortality of juvenile and adult koi, a strain of common carp. J. Aquat. Anim. Health, 12: 44-57.

Hedrick, R.P., Gilad, O., Yun, S.C., Mcdowell, T.S., Waltzek, T.B., Kelley, G.O., \& Adkison, M.A. 2005. Initial isolation and characterization of a herpes-like virus (KHV) from koi and common carp. Bull. Fish. Res. Agen. Supplement, 2: 1-7.

Hoffman, R.W., Just, J., \& El-Matbouli, M. 2002. Koi herpesvirus infection in koi and common carp in Germany. Abstract of 10 International Conference of the European Association of Fish Pathologist, Dublin, Germany, $131 \mathrm{pp}$.

Hutoran, M., Ronen, A., Perelberg, A., Ilouze, M., Dihson, A., Bejerano, I., Chen, N., \& Kotler, M. 2005. Description of an as yet unclassified DNA virus from diseased Cyprinus carpio species. J. Virol., 79: 1,9831,991 .

Neukrich, M. \& Kunz. .2001. Isolation and preliminary characterization of several viruses from koi (Cyprinus carpio) suffering gill necrosis and mortality. Bull.Eur.Ass. Fish Pathol., 21 (4): 125-135.

Perelberg, A., Smirnov, M., Hutoran, M., Diamant, A., Bejerano, I., \& Kotler, M. 2003. Epidemiological description of a new viral disease afflicting cultured Cyprinus carpio in Israel. Isr. J. Aquacult. Bamidgeh, 55: 512.

Ronen, A., Perelberg, A., Abramowitz, L., Hutoran, M., Tinman, S., Bejerano, I., Stevitz, M., \& Kotler, M. 2003. Efficient vaccine against the virus causing a lethal disease in culture Cyprinus carpio. Vaccine, 21 : 4,677-4,684.

Ronen, A., Perelberg, A., Hutoran, M., Shapira, Y., Steinitz, M., Levavi-Sivan, B., Pikarsky, E., \& Kotler, M. 2005. Prevention of a mortal disease of carps induced by the carp interstitial and gill necrosis virus (CNGV) in Israel. Bull. Fish. Agen. Suppl., 2: 9-11. 
Sano, M., Ito, T., Kurita, J., Yuasa, K., Miwa, S., \& Lida, T. 2004. Experience on common carp mass mortality in Japan. 2004. in "Transboundary fish Disease in Southeast Asia: Occurrence, Surveillance, Research and Training" (eds. By C.R. Lavilla-pitogo, and K. Nagasawa), SEAFDEC Aquaculture Department, lloilo, Philippines, p. 13-21.

Sunarto, A., Taukhid, Rukyani, A., Koesharyani, I., Supriyadi, H., Huminto, H., Agungpriyono, D.R., Pasaribu, F.H., Widodo, Herdikiawan, D., Rukmono, V., \& Prayitno, V. 2005a. Field investigation on serious disease outbreak among koi and common carp (Cyprinus carpio) in Indonesia. In Walker, P.J., R.G. Lester, and M.G. Bondad Reantaso (Eds.). Diseases in Asian Aquaculture V. Fish Health Section, Asian Fisheries Society, Manila, p. 125-136.

Sunarto, A., Sumiati, T., Koesharyani, I., Hyatt, A., \& Itami, T. 2005b. Development of cell line from tail of koi (Cyprinus carpio) and isolation of koi herpesvirus from Indonesia aquaculture. Book of abstracts $6^{\text {th }}$ Symposium on Diseases in Asian Aquaculture, 25-28 October 2005. Colombo. Srilanka, 74 pp.

Sunarto, A., Rukyani, V., \& Itami, V. 2005c. Indonesian experience on the outbreak of Koi herpesvirus in koi and carp (Cyprinus carpio). Japan Bull. Fish. Res. Agen. Supp., 2:15-21.

Sunarto, A., \& Cameron, V. 2005. Response to mass mortality of carp: an Indonesian experiences. In Subasinghe, R.P. and J.R.
Arthur (Eds.). Regional Workshop on Preparedness and Response to Aquatic Animal Health Emergencies in Asia. FAO Fisheries Proceedings. No. 4. Rome, p. 87106.

Sunarto, A. \& Cameron, A. 2006. Epidemiology and control of Koi herpesvirus in Indonesia. Proceedings of the $11^{\text {th }}$ International Society on Veterinary Epidemiology and Economics, Cairns, Australia. 4p (also available at www.sciquest.org.nz).

Tu, C., Lin, S.Y., \& Sung, H.T. 2004. Current status of Koi herpesvirus disease in Taiwan. 2004. in "Transboundary fish Disease in Southeast Asia: Occurrence, Surveillance, Research and Training" (Eds.). By C.R. Lavilla-pitogo and K. Nagasawa), SEAFDEC Aquaculture Department, Iloilo, Philippines, p. 21-24.

Waltzek, T.B., Kelley, G.O., Stone, D.M., Way, K., Hanson, L., Fukuda, H., Hirono, I., Aoki, T., Davison, A.J., \& Hedrick, R.P. 2005. Koi herpesvirus represent a third cyprinid herpesvirus (CyHV-3) in the family Herpesviridae. J. Gen. Virol., 86: 1,6591,667 .

Way, K., Le Deuff, R.M., Ecclestone, L., Feist, S.W., Dixon, P.F., Wildgoose, W.H., \& Hedrick, R.P. 2002. Isolation of a herpesvirus during disease outbreaks in adults koi carp, Cyprinus carpio, in the UK. Abstract of 10 International Conference of the European Association of Fish Pathologist, Dublin, Germany, 129 pp. 